\title{
Kapasitas Lentur Panel Bertulangan Rotan dengan Beton Mutu Tinggi Menggunakan Semen, Fly ASh dan Kapur
}

\section{The Rattan Reinforcement Panel Bending Capacity With High Quality Concrete Using Cement, Fly Ash and Lime}

\author{
Suhendro Trinugrono ${ }^{1)}$, and Nuning Trisnawati ${ }^{2)}$ \\ ${ }^{1)}$ Department of Civil Engineering, Universitas Muhammadiyah Surakarta, Jl. A. Yani Pabelan Kartasura \\ Tromol Pos I Surakarta Post Code 57102, \\ e-mail: Suhendro.Trinugroho@ums.ac.id \\ ${ }^{2)}$ Divisi Engineering, PT Mutu Utama Konstruksi, J1. Rijali No. 16 Rt. 004/04 Kel. Batu Meja - Ambon \\ e-mail: nuningtrisnaw@gmail.com
}

\begin{abstract}
ABSTRAK
Beton merupakan bahan kebutuhan untuk masyarakat modern masa kini. Di Indonesia saja hampir seluruh konstruksi bangunan menggunakan beton sebagai bahan bangunan, seperti pada konstruksi bangunan gedung, jembatan, jalan dan lainnya. Di penelitian ini bahan aditif yang digunakan adalah dengan memberikan bahan tambah seperti abu terbang (fly ash) dan kapur serta menggunakan tulangan rotan. Rotan yang digunakan mengguanakan diameter $\emptyset 0,8 \mathrm{~cm}$. Perencanaan beton dengan berdasarkan perbandingan antara semen, pasir dan kerikil adalah sesuai SK.SNI.T-15-1990-03 f'c = 45 MPa. Faktor air semen (f.a.s) yang digunakan adalah 0,3. Tujuan dari penelitian ini adalah untuk menganalisis momen lentur panel beton mutu tinggi menggunakan tulangan rotan dengan penambahan fly ash dan kapur pada umur 28 hari. Metode penelitian ini ada beberapa tahap. Tahap pertama yaitu persiapan alat dan bahan. Tahap kedua meliputi: pemeriksaan bahan, perencanaan campuran dan pembuatan adukan beton. Tahap ketiga yaitu pembuatan benda uji dan perawatan. Tahap keempat yaitu pengujian kuat tekan beton dan kuat lentur pelat. Tahap kelima yaitu analisa data, pembahasan dan kesimpulan. Hasil dari pengujuian kuat tekan beton normal 46,403 MPa; beton tambahan Fly ash (15\%) 47,534 MPa; beton tambahan kapur (15\%) 44,705 MPa; beton campuran fly ash dan kapur 49,232 MPa. Sedangkan untuk momen lentur panel beton normal, dengan penambahan fly ash, penambahan kapur dan campuran antara fly ash dan kapur berturut - turut adalah 2.860.659,00 N.mm; 201.159,00 N.mm; 2.951.784,00 N.mm; 2.918.034,00 N.mm.
\end{abstract}

Kata kunci : panel beton, rotan, fly ash, kapur

\begin{abstract}
Concrete is a material requirement for modern society of today. In Indonesia, almost all building constructions using concrete as a building material, such as the construction of buildings, bridges, roads and others. In this final project additive used is to provide added material such as fly ash and lime as well as the use of reinforcement rattan. Rattan is used using diameter $\emptyset 0.8$ $\mathrm{cm}$. Planning concrete is based on a comparison between the concrete with cement, sand, and gravel are appropriate SK.SNI.T-15-1990-03 f'c = 45 MPa. The used water cement ratio (fas) is 0.3. The object of this study was to analyze the bending moment of high strength concrete panels using reinforcement rattan with the addition of fly ash and lime at 28 days. This study method, there are some phases. The first phase is the preparation of equipment and materials. The second phase includes: materials test, the planning mixture and manufacture of the concrete mixture. Third phase is the manufacture and curing of the test specimen. Fourth phase is the testing of concrete compressive strength and panel bending strength. The fifth phase is data analysis, explanations and conclusions. The results of testing compressive strength of normal concrete 46.403 $\mathrm{MPa}$; additional fly ash concrete (15\%) $47.534 \mathrm{MPa}$; additional concrete limestone (15\%) $44.705 \mathrm{MPa}$; concrete mixture of fly ash and lime 49.232 MPa. Whereas for the normal concrete panels of bending moment, with the addition of fly ash, lime, mixture of fly ash and lime respectively also is $2.860 .659,00$ N.mm; $201.159,00$ N.mm; 2.951.784,00 N.mm; 2.918.034,00 N.mm.
\end{abstract}

Keywords: concrete panels, rattan, fly ash, lime

\section{PENDAHULUAN}

Beton merupakan bahan kebutuhan untuk masyarakat modern masa kini. Karena teknologi semakin maju maka penggunaan beton dituntut untuk semakin meningkat dari segi kualitas maupun kuantitas. Beton biasa merupakan bahan gabungan yang terdiri dari air, agregat dan semen. Kuat tekan beton $\left(f^{\prime} c\right) 10-20 \mathrm{MPa}$ untuk beton tidak tahan gempa, sedangkan kuat tekan lebih dari $20 \mathrm{MPa}$ di desain tahan gempa. Beton mutu tinggi merupakan beton yang dibuat dari campuran bahan (semen, agregat, air) dan dengan penambahan zat aditif sesuai dengan perbandingan sehingga bahan itu dapat membentuk kekuatan beton yang lebih tinggi. Kuat tekan beton mutu tinggi ( $f^{\prime} \mathrm{c}$ ) yang di syaratkan adalah > 41,5 MPa tercantum di dalam SNI 03-6468-2000. Karena harga baja tulangan mahal dan sulit untuk diperbaharui sehingga keberadaannya suatu saat akan habis, maka penelitian ini menggunakan tulangan rotan. Adapun tujuan dari kan bagi perancang bangunan, sebagai alternatif untuk dinding yang kuat, bagi pengguna bangunan, dapat menghemat biaya dan waktu dalam pembangunan dinding panel dan bagi perkembangan ilmu, dapat memberikan manfaat dalam dunia pendidikan dan pengetahuan dalam bidang teknik sipil khususnya teknologi beton panel mutu tinggi dengan menggunakan tulangan rotan.

Didalam metode penelitian ini ialah :

\section{METODE PENELITIAN}

1. Material / bahan yang digunakan

Bahan Penyusun untuk beton panel ialah :

- Air dari Lab. Teknik Sipil Univ. Muhammadiyah Surakarta.

- Semen portland tipe I dengan merk Gresik.

- Bahan ikat kapur berasal dari UD. Galan Putra, Klaten. Penggunaan kapur sebanyak $15 \%$ untuk setiap benda uji.

- Agregat halus (pasir) yang dipergunakan adalah pasir yang berasal dari gunung merapi. 
penelitian ini adalah: menganalisis sifat karakteristik dari rotan dan menganalisis momen lentur maksimal panel mutu tinggi dengan tulangan rotan dengan penambahan abu terbang (fly ash) dan kapur pada umur 28 hari. Manfaat dari penelitian ini diharap-
- Agregat kasar berupa batu pecah dengan ukuran maksimum 20 mm yang berasal dari Wonogiri.

- Fly ash berjenis limbah batu bara, kelas C berasal dari PT. Iskandar indah printing textile, Kerten, Laweyan, Solo , penggunaan fly ash sebanyak $15 \%$ untuk setiap benda uji.

1. Kuat tekan beton yang direncanakan adalah $45 \mathrm{MPa}$ dengan metode Road Note No.4.

$90 \mathrm{~cm}$ ialah pengujian kuat lentur dengan satu titik beban ditengah bentang pada umur 28 hari.

2. Pengujian yang dilaksanakan pada rotan adalah pengujian kuat tarik.

3. Pengujian yang dilaksanakan pada panel berdimensi $8 \mathrm{~cm} \times 50$ $\mathrm{cm} \times 100 \mathrm{~cm}$ dengan penulangan satu arah pakai rotan diameter $0,8 \mathrm{~cm}$ dengan panjang vertikal $40 \mathrm{~cm}$ dan panjang horizontal tabung le chatelier, alat vicat test, conus, uji lentur dan alat yang terkait pengujian.

5. Tahapan penelitian sebagaimana pada gambar 1 .
4. Peralatan yang dipakai ialah saringan agregat, sieve shaker,

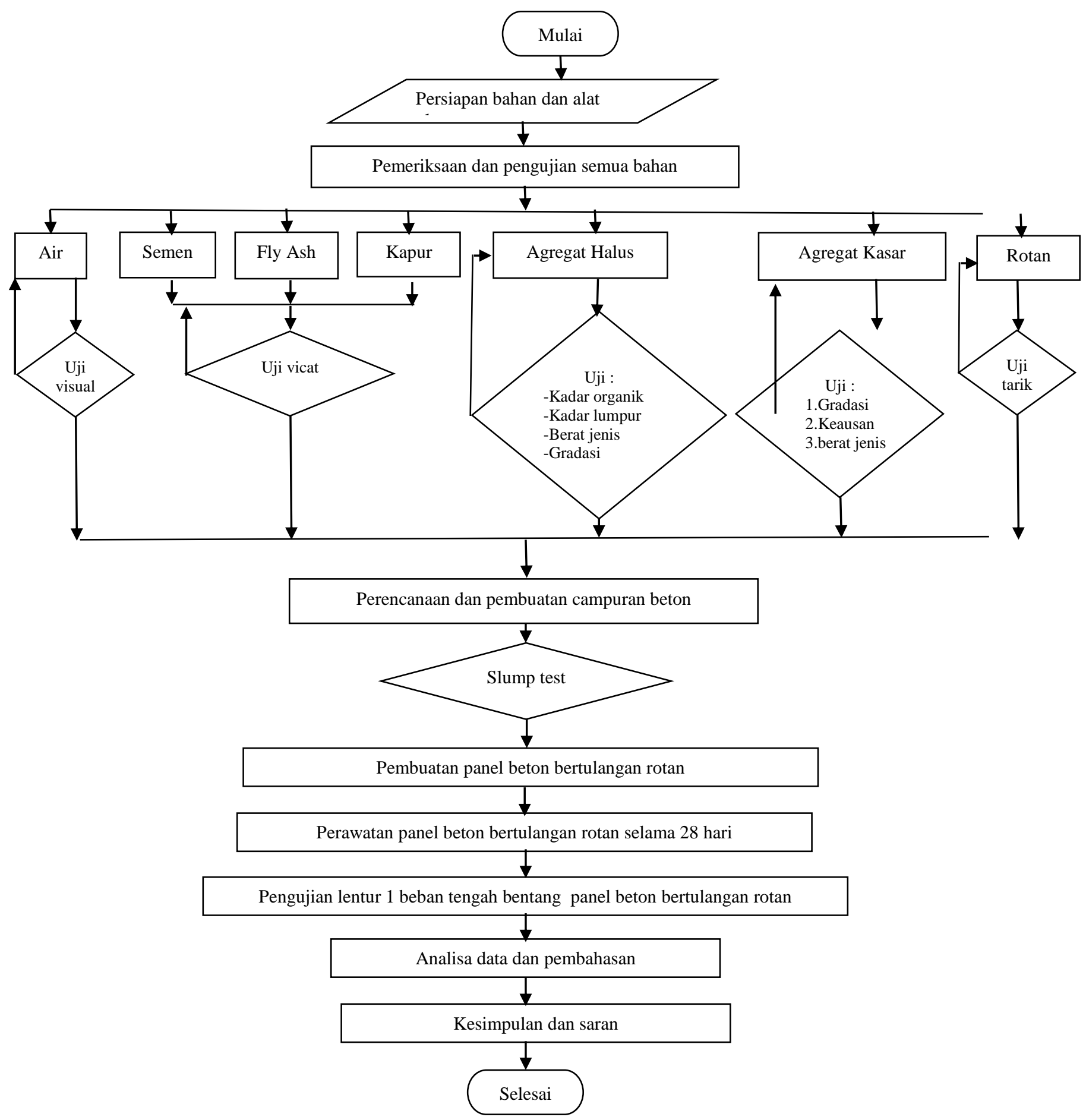

Gambar 1. Tahapan penelitian 


\section{HASIL DAN PEMBAHASAN}

Hasil pengujian yang didapatkan selain pengujian air, semen, fly ash dan kapur, ialah sebagai berikut :

\section{Hasil pengujian agregat halus}

Tabel 1. Hasil pengujian agregat halus

\begin{tabular}{|c|c|c|c|}
\hline $\begin{array}{l}\text { Jenis } \\
\text { pengujian }\end{array}$ & $\begin{array}{c}\text { Hasil } \\
\text { pengujian }\end{array}$ & $\begin{array}{c}\text { Syarat } \\
\text { SNI 03-6821- } \\
2002 \\
\end{array}$ & Rekomendasi \\
\hline $\begin{array}{l}\text { Kandungan } \\
\text { lumpur }\end{array}$ & $3,14 \%$ & $5 \%$ & $\begin{array}{l}\text { Memenuhi } \\
\text { syarat }\end{array}$ \\
\hline $\begin{array}{l}\text { Kandungan } \\
\text { Organik }\end{array}$ & $\begin{array}{c}\text { No.3 } \\
\text { (Orange) }\end{array}$ & No. $1-3$ & $\begin{array}{l}\text { Memenuhi } \\
\text { syarat }\end{array}$ \\
\hline $\begin{array}{l}\text { Nilai Saturated } \\
\text { Surface Dry } \\
(S S D)\end{array}$ & 3,82 & $\begin{array}{l}\text { Setengah dari } \\
\text { tinggi kerucut }\end{array}$ & $\begin{array}{l}\text { Memenuhi } \\
\text { syarat }\end{array}$ \\
\hline Specific gravity & 2,70 & $\begin{array}{c}2,5-2,7 \\
\mathrm{gram} / \mathrm{cm}^{3}\end{array}$ & $\begin{array}{l}\text { Memenuhi } \\
\text { syarat }\end{array}$ \\
\hline Absorption & $3,52 \%$ & $1-2 \%$ & $\begin{array}{l}\text { Tidak } \\
\text { memenuh } \\
\text { syarat }\end{array}$ \\
\hline $\begin{array}{l}\text { Modulus halus } \\
\text { butiran }\end{array}$ & 3,52 & $1,5-3,8$ & $\begin{array}{l}\text { Memenuhi } \\
\text { syarat }\end{array}$ \\
\hline
\end{tabular}

Tabel 2. Gradasi pasir

\begin{tabular}{cccccccc}
\hline $\begin{array}{c}\mathrm{N} \\
\mathrm{o}\end{array}$ & $\begin{array}{c}\text { Ukuran } \\
\text { Ayakan } \\
(\mathrm{mm})\end{array}$ & $\begin{array}{c}\text { Berat } \\
\text { Pasir } \\
(\mathrm{gr})\end{array}$ & $\begin{array}{c}\text { Berat Pasir } \\
\text { Terkoreksi } \\
(\mathrm{gr})\end{array}$ & $\begin{array}{c}\text { Persentase } \\
\text { Pasir } \\
\text { Tertinggal } \\
(\%)\end{array}$ & $\begin{array}{c}\text { Persentase } \\
\text { Komulatif }(\%) \\
\text { Tertingg } \\
\text { al }\end{array}$ & $\begin{array}{c}\text { Lolos } \\
\text { IV }\end{array}$ \\
\hline 1. & 9.5 & 0 & 0.00 & 0.00 & 0 & 100 & $100-100$ \\
2. & 4,75 & 10 & 10,00 & 2,00 & 2,00 & 98,00 & $95-100$ \\
3. & 2,36 & 40 & 40,00 & 8,00 & 10,00 & 90,00 & $95-100$ \\
4. & 1,18 & 110 & 110,00 & 22,00 & 32,00 & 68,00 & $90-100$ \\
5. & 0,6 & 100 & 100,00 & 20,00 & 52,00 & 48,00 & $80-100$ \\
6. & 0,3 & 90 & 90,00 & 18,00 & 70,00 & 30,00 & $15-50$ \\
7. & 0,15 & 80 & 80,00 & 16,00 & 86,00 & 14,00 & $0-15$ \\
8. & pan & 70 & 70,00 & 14,00 & 100 & 0,00 & - \\
& & 500 & 500 & 100,00 & 352,00 & 448,0 & \\
& & & & & & & \\
\hline
\end{tabular}

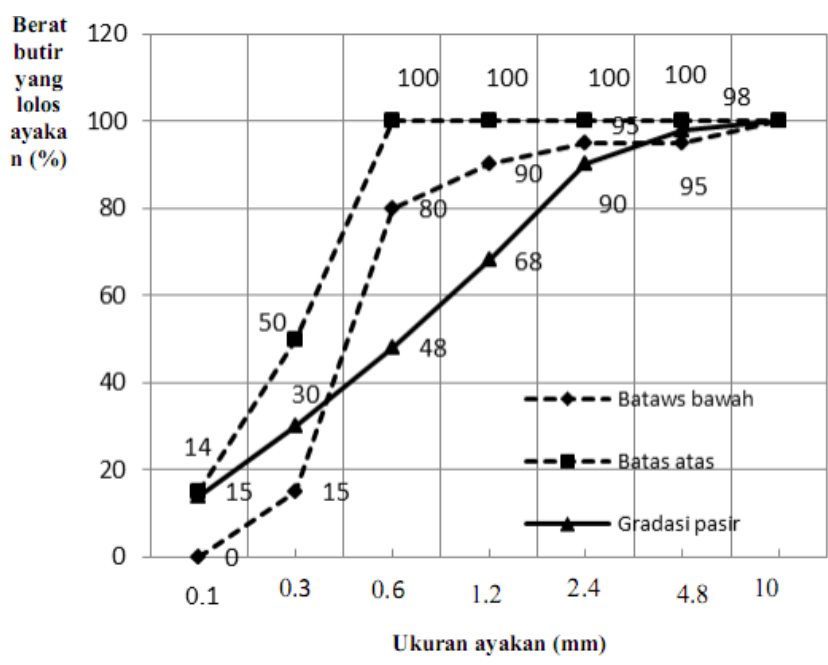

Gambar 2. Grafik pemeriksaan gradasi agregat halus

\section{Pengujian agregat kasar}

Tabel 3. Hasil pengujian agregat kasar

\begin{tabular}{|c|c|c|c|}
\hline Jenis pengujian & $\begin{array}{c}\text { Hasil } \\
\text { pengujian }\end{array}$ & $\begin{array}{c}\text { Syarat } \\
\text { SNI 15-1990-03 }\end{array}$ & Rekomendasi \\
\hline $\begin{array}{l}\text { Keausan agregat } \\
\text { kerikil }\end{array}$ & $35,10 \%$ & $40 \%$ & $\begin{array}{l}\text { Memenuhi } \\
\text { syarat }\end{array}$ \\
\hline $\begin{array}{l}\text { Bulk Specific } \\
\text { gravity } 1\end{array}$ & 2,52 & $\begin{array}{c}2,5-2,7 \\
\mathrm{gram} / \mathrm{cm}^{3}\end{array}$ & $\begin{array}{l}\text { Memenuhi } \\
\text { syarat }\end{array}$ \\
\hline Absorption & 3,54 & $<3 \%$ & $\begin{array}{c}\text { Tidak } \\
\text { memenuhi } \\
\text { syarat }\end{array}$ \\
\hline $\begin{array}{l}\text { Modulus halus } \\
\text { butiran }\end{array}$ & 7,638 & $5-8$ & $\begin{array}{l}\text { Memenuhi } \\
\text { syarat }\end{array}$ \\
\hline
\end{tabular}

Tabel 4. Gradasi agregat kasar (batu pecah)

\begin{tabular}{|c|c|c|c|c|c|c|c|}
\hline \multirow[b]{2}{*}{ No } & \multirow{2}{*}{$\begin{array}{c}\text { Ukuran } \\
\text { Ayakan } \\
(\mathrm{mm})\end{array}$} & \multirow{2}{*}{$\begin{array}{c}\text { Berat } \\
\text { Kerikil } \\
\text { (gr) }\end{array}$} & \multirow{2}{*}{$\begin{array}{l}\text { Berat Pasir } \\
\text { Terkoreksi } \\
\quad \text { (gr) }\end{array}$} & \multirow{2}{*}{$\begin{array}{c}\text { Persentase } \\
\text { Kerikil } \\
\text { Tertinggal } \\
(\%)\end{array}$} & \multicolumn{2}{|c|}{ Persentase Komulatif } & \multirow{2}{*}{$\begin{array}{c}\% \text { Butir } \\
\text { maks } \\
20 \mathrm{~mm}\end{array}$} \\
\hline & & & & & $\begin{array}{l}(\%) \\
\text { Tertinggal }\end{array}$ & Lolos & \\
\hline 1 & 25 & 30 & 30,00 & 5,55 & 5,55 & 94.45 & 100 \\
\hline 2 & 19 & 125 & 125,00 & 23,11 & 28,65 & 71,35 & $95-100$ \\
\hline 3 & 12,5 & 180 & 180,00 & 33,27 & 61,92 & 38,08 & $25-55$ \\
\hline 4 & 9,5 & 70 & 70,00 & 12,94 & 74,86 & 2,14 & $0-10$ \\
\hline 5 & 4,75 & 110 & 110,00 & 20,33 & 95,19 & 4,81 & $\begin{array}{ll}- \\
\text { - }\end{array}$ \\
\hline 6 & 2,36 & 20 & 20,00 & 3,70 & 98,89 & 1,11 & - \\
\hline 7 & 1,18 & 0 & 0,00 & 0.00 & 98,89 & 1,11 & - \\
\hline 8 & 0,6 & 5 & 5,00 & 0,92 & 99,82 & 0,18 & - \\
\hline 9 & 0,3 & 1 & 1,00 & 0,18 & 100,00 & 0,00 & - \\
\hline 10 & 0,15 & 0 & 0,00 & 0,00 & 100,00 & 0,00 & - \\
\hline 11 & pan & 0 & 0,00 & 0,00 & - & 0,00 & - \\
\hline & Total & 541 & 541 & 100.00 & 763,77 & $23, .23$ & \\
\hline
\end{tabular}

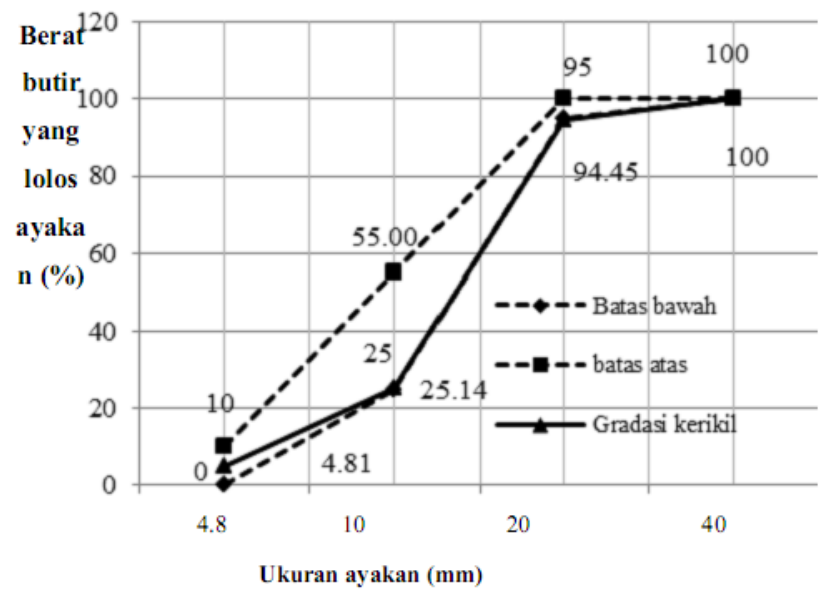

Gambar 3. Grafik pemeriksaan gradasi agregat kasar

\section{Pengujian rotan}

Rotan dalam panel beton ini berfungsi sebagai tulangan panel beton. Untuk mengetahui kekuatan rotan dilakukan uji kuat tarik. Kuat tarik (tensile strength) ialah tegangan maksimum yang dicapai selama bahan diuji tarik.

Tabel 5. Hasil pengujian kuat tarik rotan

\begin{tabular}{|c|c|c|c|c|c|}
\hline No & Sampel & $\begin{array}{c}\text { Tensile } \\
\text { strain at } \\
\text { Break } \\
\left(\begin{array}{l}\text { Standard }) \\
(\mathrm{mm} / \mathrm{mm})\end{array}\right.\end{array}$ & $\begin{array}{c}\text { Luas } \\
\text { Tulangan } \\
\left(\mathrm{cm}^{2}\right)\end{array}$ & $\begin{array}{c}\text { Tensile } \\
\text { strain at } \\
\text { Break } \\
\left(\begin{array}{c}\text { Standard }) \\
(\mathrm{MPa})\end{array}\right.\end{array}$ & $\begin{array}{c}\text { Modulus } \\
\text { (Automatic) } \\
(\mathrm{MPa})\end{array}$ \\
\hline 1 & Sampel 1 & 0,386 & 84,403 & 99,033 & 901.066 \\
\hline 2 & Sampel 2 & 0,387 & 84,403 & 99,034 & 901.066 \\
\hline 3 & Sampel 3 & 0,385 & 84,403 & 99,032 & 901.066 \\
\hline
\end{tabular}

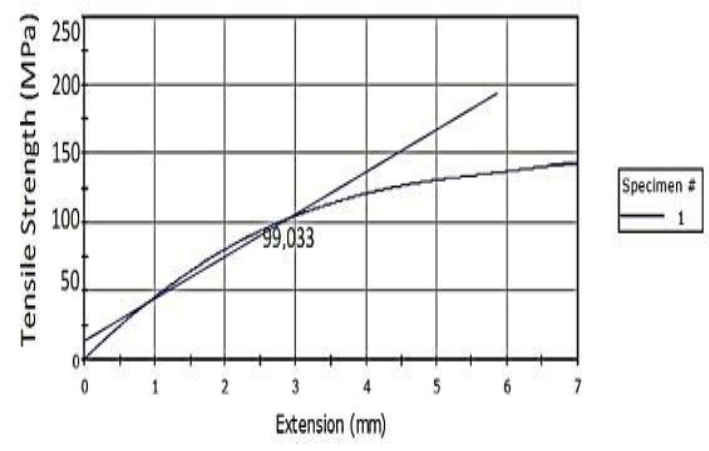

Gambar 4. Grafik pengujian kuat tarik rotan 
Tabel 6. Tegangan dan regangan pada rotan

\begin{tabular}{|c|c|c|c|c|c|c|c|}
\hline \multirow{3}{*}{ No. } & \multicolumn{2}{|c|}{ Beban (P) } & \multirow{3}{*}{$\begin{array}{c}\text { Perpendekan } \\
(\Delta \mathrm{L}) \\
\mathrm{mm}\end{array}$} & \multirow{3}{*}{$\begin{array}{c}\sigma=\mathrm{P} / \mathrm{A} \\
\left(\mathrm{Kg} / \mathrm{cm}^{2}\right)\end{array}$} & \multirow[t]{3}{*}{$\varepsilon=\Delta \mathrm{L} / \mathrm{L}_{0}$} & \multicolumn{2}{|c|}{ Koreksi } \\
\hline & & & & & & \multirow{2}{*}{$\begin{array}{c}\text { Analitis } \\
\left(\varepsilon^{\prime}\right)\end{array}$} & \multirow{2}{*}{$\begin{array}{c}\text { Grafis } \\
\left(\varepsilon^{\prime}\right)\end{array}$} \\
\hline & $\mathrm{kN}$ & $\mathrm{Kg}$ & & & & & \\
\hline 1 & 0 & 0 & 0 & 0 & 0.00024 & 0.00000 & 0.000 \\
\hline 2 & 1 & 100 & 0.061 & 8440.300 & 0.00031 & 0.00007 & 0.000 \\
\hline 3 & 1.47 & 147 & 0.086 & 12407.241 & 0.00043 & 0.00019 & 0.000 \\
\hline 4 & 1.72 & 172 & 0.091 & 14517.316 & 0.00046 & 0.00022 & 0.000 \\
\hline 5 & 1.893 & 189.3 & 0.102 & 15977.488 & 0.00051 & 0.00027 & 0.000 \\
\hline 6 & 2.056 & 205.6 & 0.126 & 17353.257 & 0.00063 & 0.00039 & 0.000 \\
\hline 7 & 2.209 & 220.9 & 0.157 & 18644.623 & 0.00078 & 0.00055 & 0.001 \\
\hline 8 & 2.352 & 235.2 & 0.188 & 19851.586 & 0.00094 & 0.00070 & 0.001 \\
\hline 9 & 2.485 & 248.5 & 0.219 & 20974.146 & 0.00110 & 0.00086 & 0.001 \\
\hline 10 & 2.608 & 260.8 & 0.251 & 22012.302 & 0.00126 & 0.00102 & 0.001 \\
\hline 11 & 2.721 & 272.1 & 0.262 & 22966.056 & 0.00131 & 0.00107 & 0.001 \\
\hline 12 & 3.124 & 312.4 & 0.293 & 26367.497 & 0.00147 & 0.00123 & 0.001 \\
\hline 13 & 3.506 & 350.6 & 0.324 & 29591.692 & 0.00162 & 0.00138 & 0.001 \\
\hline 14 & 3.699 & 369.9 & 0.355 & 31220.670 & 0.00178 & 0.00154 & 0.002 \\
\hline 15 & 3.862 & 386.2 & 0.386 & 32596.439 & 0.00193 & 0.00169 & 0.002 \\
\hline \multirow[t]{2}{*}{16} & 3.789 & 378.9 & 0.391 & 31980.297 & 0.00196 & 0.00172 & 0.002 \\
\hline & & & & 30486.364 & 0.00205 & & \\
\hline
\end{tabular}

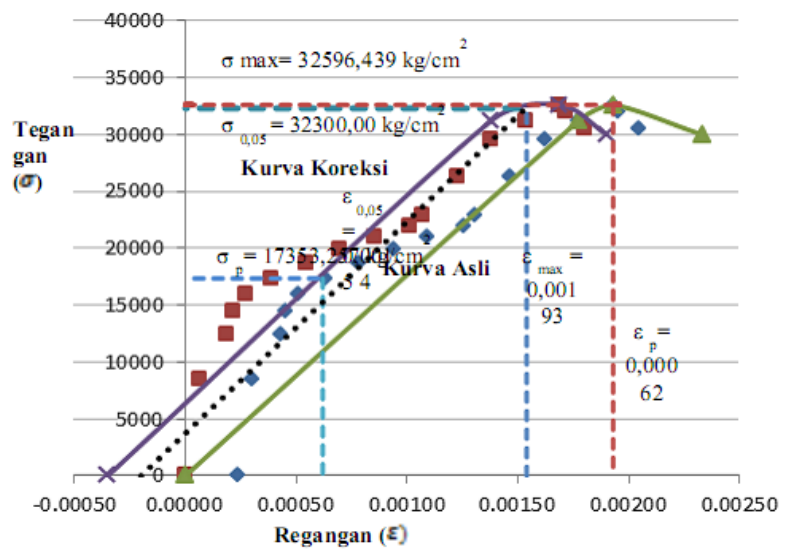

Gambar 5. Grafik tegangan regangan pada rotan

\section{Pengujian Slump}

Tabel .7. Hasil Pengujian slump adukan beton

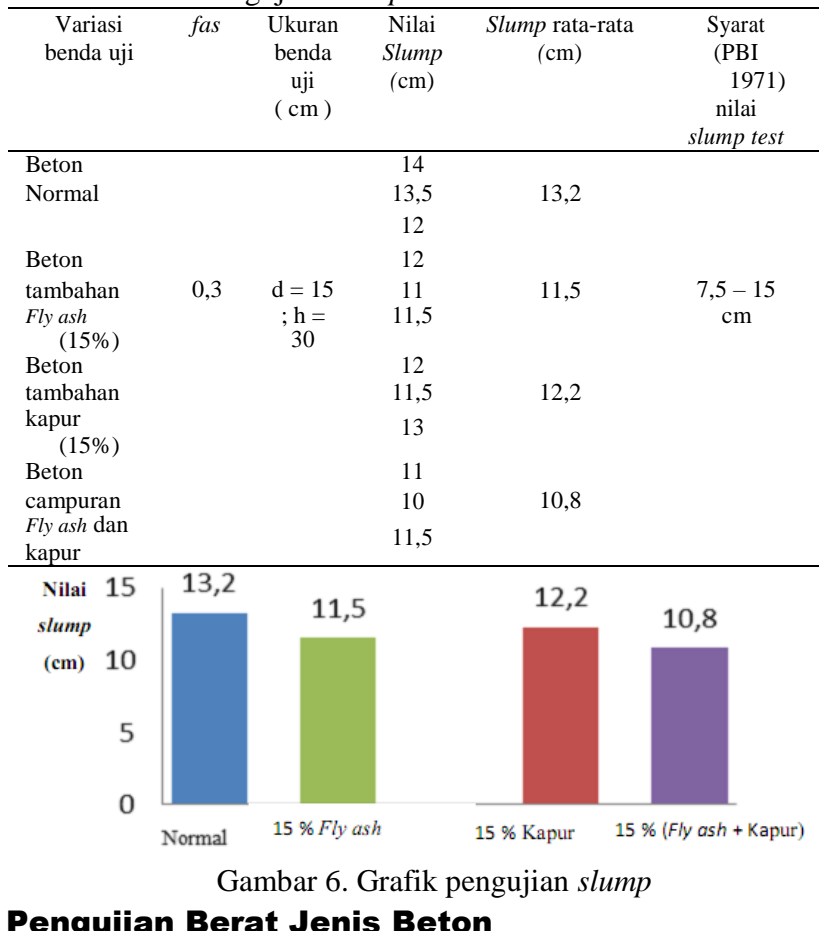

Berat jenis beton diketahui dengan cara menimbang dan mengukur tinggi, sehingga didapatkan berat dan volume benda uji tersebut. Hasil pemeriksaan berat jenis beton setelah perawatan beton dapat dilihat pada Tabel 8 .

Tabel 8. Hasil pengujian berat jenis silinder beton

\begin{tabular}{lccc}
\hline \multicolumn{1}{c}{ Variasi } & $\begin{array}{c}\text { Volume } \\
\text { silinder } \\
\left(\mathrm{cm}^{3}\right)\end{array}$ & $\begin{array}{c}\text { Berat } \\
\text { silinder } \\
(\mathrm{gram})\end{array}$ & $\begin{array}{c}\text { Berat jenis } \\
\left(\mathrm{gram} / \mathrm{cm}^{3}\right)\end{array}$ \\
\hline Beton normal & & 12045 & 2,272 \\
Beton tambahan Fly ash $(15 \%)$ & 5301,44 & 11890 & 2,243 \\
Beton tambahan kapur (15\%) & & 12145 & 2,291 \\
$\begin{array}{l}\text { Beton campuran Fly ash } \text { dan } \\
\text { kapur }\end{array}$ & & 12035 & 2,270 \\
\hline
\end{tabular}

Tabel 9. Hasil pengujian berat jenis panel beton

\begin{tabular}{|c|c|c|c|c|}
\hline Variasi & $\begin{array}{l}\text { Volume } \\
\text { Panel } \\
\left(\mathrm{cm}^{3}\right)\end{array}$ & $\begin{array}{c}\text { Berat Beton } \\
\text { (gram) }\end{array}$ & $\begin{array}{l}\text { Berat jenis } \\
\left(\mathrm{gram} / \mathrm{cm}^{3}\right)\end{array}$ & $\begin{array}{l}\text { Bj rata-rata } \\
\left(\mathrm{gram} / \mathrm{cm}^{3}\right)\end{array}$ \\
\hline \multirow{3}{*}{ Beton normal } & & 95660 & 2,392 & \multirow{3}{*}{2,392} \\
\hline & & 95660 & 2,392 & \\
\hline & & 95660 & 2,392 & \\
\hline \multirow{3}{*}{$\begin{array}{l}\text { Beton tambahan } \\
\text { Fly ash }(15 \%)\end{array}$} & & 99170 & 2,479 & \multirow{3}{*}{2,479} \\
\hline & & 99170 & 2,479 & \\
\hline & 40000 & 99170 & 2,479 & \\
\hline \multirow{3}{*}{$\begin{array}{l}\text { Beton tambahan } \\
\text { kapur }(15 \%)\end{array}$} & & 99170 & 2,479 & \multirow{3}{*}{2,479} \\
\hline & & 99170 & 2,479 & \\
\hline & & 99170 & 2,479 & \\
\hline \multirow{3}{*}{$\begin{array}{l}\text { Beton campuran } \\
\text { Fly ash dan kapur }\end{array}$} & & 102680 & 2,567 & \multirow{3}{*}{2,567} \\
\hline & & 102680 & 2,567 & \\
\hline & & 102680 & 2,567 & \\
\hline
\end{tabular}

\section{Pengujian Kuat Tekan Beton}

Tabel 10. Hasil pengujian kuat tekan silinder beton

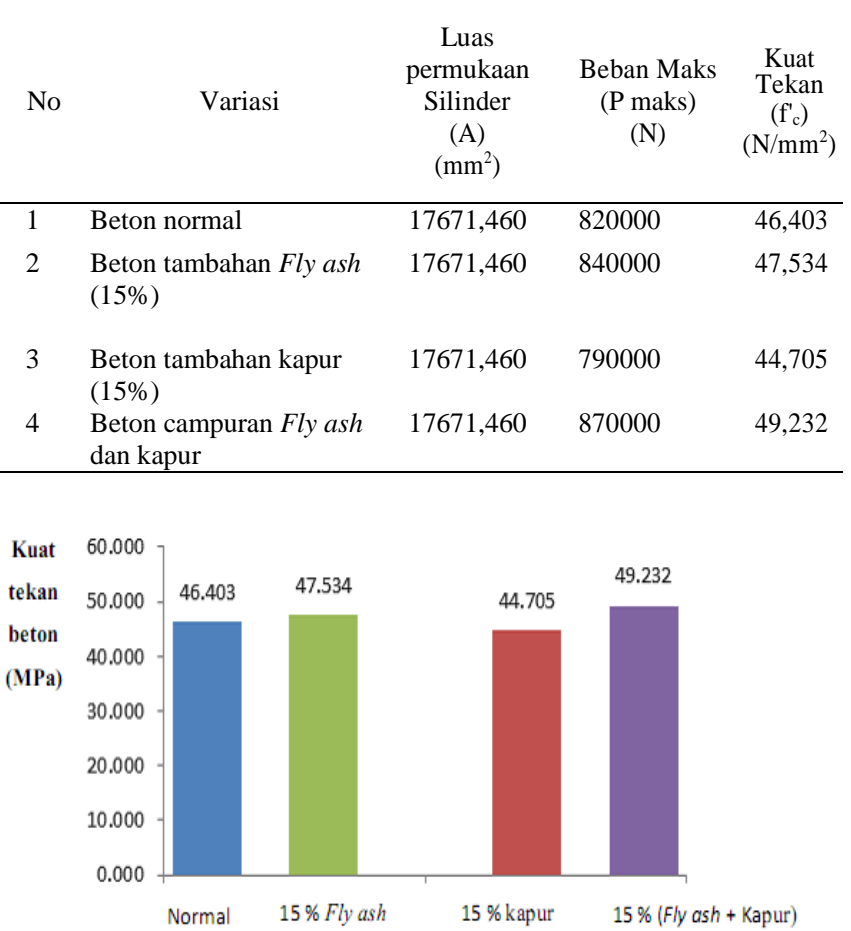

Gambar 7. Grafik pengujian kuat tekan silinder beton

Dari Tabel 10. di atas hasil pengujian kuat tekan silinder 
beton didapat kuat tekan silinder beton normal adalah 46,403 MPa. Hasil pengujian kuat tekan silinder beton tambahan fly ash adalah 47,534 MPa. Hasil pengujian kuat tekan silinder beton tambahan kapur adalah 44,705 MPa. Hasil pengujian kuat tekan silinder beton tambahan fly ash dan kapur adalah 49,232 MPa dengan luas permukaan silinder $17671,46 \mathrm{~mm}^{2}$. Jadi dari hasil pengujian laboratorium kuat tekan beton mutu tinggi sudah sesuai standar kuat tekan beton mutu tinggi yang disyaratkan yaitu $41,5 \mathrm{MPa}$ sesuai dengan SNI 03-6468-2000.

\section{Pengujian Momen Lentur Panel Beton Hasil uji laboratorium}

Pada pengujian momen lentur panel beton hasil uji laboratorium diperhitungkan 2 jenis beban yaitu beban terpusat $P$ (oleh benda uji) dan beban terbagi rata q (oleh berat sendiri). hasil pengujian momen lentur rata-rata panel beton normal didapat 2,523 $\mathrm{kN}$.m. Untuk hasil pengujian momen lentur rata-rata panel beton dengan penambahan fly ash didapat 2,654 kN.m. Untuk hasil pengujian momen lentur rata-rata panel beton dengan penambahan kapur didapat 2,817 kN.m. Untuk hasil pengujian momen lentur rata-rata panel beton dengan penambahan fly ash dan kapur didapat 2,708 N.mm. Dengan melihat hasil uji laboratorium momen lentur pada panel beton dengan penambahan kapur kekuatan momen lentur berpengaruh lebih besar dibandingkan dengan beton normal, beton dengan penambahan fly ash dan beton campuran antara penambahan kapur serta fly ash.

\section{Hasil analisis teoritis}

Pada pengujian momen lentur panel beton hasil analisis teoritis berdasarkan gaya dalam pada panel beton. Hasil analisis teoritis momen lentur panel beton dengan penambahan fly ash didapat 1,377 kN.m. Untuk hasil analisis teoritis momen lentur panel beton dengan penambahan kapur didapat 1,376 kN.m. Untuk hasil analisis teoritis momen lentur panel beton dengan penambahan fly ash dan kapur didapat 1,378 kN.m. Dengan melihat hasil analisis teoritis momen lentur pada panel beton dengan penambahan fly ash kekuatan momen lentur cenderung berpengaruh lebih tinggi dari beton normal, beton dengan penambahan kapur dan beton campuran antara penambahan kapur serta fly ash.

Tabel 11. Prosentase selisih rata-rata hasil analisa dengan hasil uji laboratorium

\begin{tabular}{|c|c|c|c|c|c|}
\hline Variasi benda uji & $\begin{array}{c}\text { Hasil uji } \\
\text { laboratorium } \\
\text { (kN.m) }\end{array}$ & $\begin{array}{c}\text { Hasil } \\
\text { hitungan } \\
\text { analisis } \\
\text { (kN.m) }\end{array}$ & $\begin{array}{l}\text { Selisih } \\
\text { hasil } \\
\text { (kN.m) }\end{array}$ & $\begin{array}{c}\text { Prosentase } \\
\text { selisih } \\
(\%)\end{array}$ & $\begin{array}{c}\text { Prosentase } \\
\text { selisih rata- } \\
\text { rata } \\
(\%)\end{array}$ \\
\hline \multirow{3}{*}{ Beton normal } & 2,523 & 1,377 & 1,505 & 45,423 & \multirow{3}{*}{45,423} \\
\hline & 2,523 & 1,377 & 0,820 & 45,423 & \\
\hline & 2,523 & 1,377 & 1,114 & 45,423 & \\
\hline \multirow{3}{*}{$\begin{array}{l}\text { Beton tambahan } \\
\text { Fly ash }(15 \%)\end{array}$} & 2,654 & 1,377 & 1,211 & 48,103 & \multirow{3}{*}{48,103} \\
\hline & 2,654 & 1,377 & 1,081 & 48,103 & \\
\hline & 2,654 & 1,377 & 1,537 & 48,103 & \\
\hline \multirow{3}{*}{$\begin{array}{l}\text { Beton tambahan } \\
\text { kapur }(15 \%)\end{array}$} & 2,817 & 1,376 & 1,212 & 51,140 & \multirow{2}{*}{51,140} \\
\hline & 2,817 & 1,376 & 1,897 & 51,140 & \\
\hline & 2,817 & 1,376 & 1,212 & 51,140 & \multirow{4}{*}{49,118} \\
\hline Beton tambahan & 2,708 & 1,378 & 0,558 & 49,118 & \\
\hline Fly ash dan kapur & 2,708 & 1,378 & 1,896 & 49,118 & \\
\hline$(15 \%)$ & 2,708 & 1,378 & 1,537 & 49,118 & \\
\hline
\end{tabular}

\section{Kesimpulan}

Berdasarkan hasil analisis maka dapat diperoleh beberapa kesimpulan sebagai berikut:

1. Hasil semua bahan beton mutu tinggi memenuhi syarat. Hasil uji laboratorium rata-rata kuat tarik pada rotan adalah 99,033
MPa.

2. Hasil uji laboratorium kuat tekan pada silinder beton beton dengan penambahan fly ash kuat tekan beton berpengaruh lebih besar dibandingkan dengan beton normal dan beton dengan penambahan kapur. Pengujian kuat tekan silinder beton dengan menggunakan penambahan fly ash adalah 47,534 MPa. Hasil pengujian laboratorium kuat tekan beton mutu tinggi sudah melebihi standar kuat tekan beton mutu tinggi yang disyaratkan yaitu 41,5 MPa sesuai dengan SNI 03-6468-2000.

3. Pengujian momen lentur rata-rata panel beton normal didapat $2.523 \mathrm{kN}$.m. Untuk hasil pengujian momen lentur rata-rata panel beton dengan penambahan fly ash didapat 2.654 kN.m. Untuk hasil pengujian momen lentur rata-rata panel beton dengan penambahan kapur didapat 2.817 kN.m. Untuk hasil pengujian momen lentur rata-rata panel beton dengan penambahan fly ash dan kapur didapat 2.708 kN.m. Dengan melihat hasil uji laboratorium momen lentur pada panel beton dengan penambahan kapur kekuatan momen lentur berpengaruh lebih besar dibandingkan dengan beton normal, beton dengan penambahan fly ash dan beton campuran antara penambahan kapur serta fly ash

4. Analisis teoritis momen lentur panel beton normal didapat 1.3767 kN.m. Untuk hasil analisis teoritis momen lentur panel beton dengan penambahan fly ash didapat $1.377 \mathrm{kN} . \mathrm{m}$. Untuk hasil analisis teoritis momen lentur panel beton dengan penambahan Kapur didapat 1.376 kN.m. Untuk hasil analisis teoritis momen lentur panel beton dengan penambahan fly ash dan kapur didapat 1.377 kN.mm. Dengan melihat hasil analisis teoritis momen lentur pada panel beton dengan penambahan fly ash kekuatan momen lentur berpengaruh lebih besar dibandingkan dengan beton normal, beton dengan penambahan kapur dan beton campuran antara penambahan kapur serta fly ash.

5. Perbandingan hasil uji laboratorium dan analisis teoritis momen lentur panel beton normal adalah $44.752 \%$. Untuk hasil perbandingan hasil uji laboratorium dan analisis teoritis momen lentur panel beton dengan penambahan fly ash adalah $47.832 \%$. Untuk hasil perbandingan hasil uji laboratorium dan analisis teoritis momen lentur panel beton dengan penambahan kapur adalah $50.535 \%$. Untuk hasil perbandingan hasil uji laboratorium dan analisis teoritis momen lentur panel beton dengan penambahan fly ash dan kapur adalah $46.487 \%$. Dengan melihat selisih hasil dari pengujian dan analisis teori di atas dapat disimpulkan bahwa hasil pengujian laboratorium lebih besar dari teoritisnya, sehingga penelitian ini layak digunakan.

Dengan demikian perlu dilakukan penelitian lebih lanjut mengenai panel beton dengan menggunakan tulangan rotan dengan bahan baku lainnya, pengukuran diameter rotan yang lebih teliti untuk keperluan hitungan analisis momen lentur panel beton itu sendiri, perlu dicoba melakukan penelitian lanjutan dengan menggunakan rotan dengan diameter yang lebih besar dan diameter yang lebih kecil supaya didapatkan perbandingan yang tepat dan ekonomis serta penelitian lebih lanjut mengenai panel beton dengan menggunakan tulangan rotan dengan dimensi panel yang lebih besar, supaya didapatkan alternative penggunaan panel diberbagai tempat.

\section{DAFTAR PUSTAKA}

Asroni, A, 2001. Struktur Beton 1, Jurusan Teknik Sipil, Fakultas Teknik, Universitas Muhammadiyah Surakarta, Surakarta. Departemen Pekerjaan Umum, 1971. Peraturan Beton Bertulang Indonesia Umum, Jakarta

Departemen Pekerjaan Umum, 1982. Persyaratan Umum Bahan Bangunan di Indonesia, Departemen Pekerjaan Umum, Jakarta.

Departemen Pekerjaan Umum, 1990. "Tata cara pembuatan rencana campuran beton normal", Departemen Pekerjaan Umum, Jakarta. 
Departemen Pekerjaan Umum, 2000. "Tata cara perencanaan campuran beton berkekuatan tinggi dengan semen portland dan abu terbang", Departemen Pekerjaan Umum, Jakarta.

Departemen Pekerjaan Umum, 1994. "Tata cara perencanaan dinding struktrur pasangan blok beton berongga bertulang", Departemen Pekerjaan Umum, Jakarta.

Departemen Pekerjaan Umum, 2002. "Specifikasi agregat rimgan untuk batu cetak beton pasangan dinding”, Departemen Pekerjaan Umum, Jakarta.

Departemen Pekerjaan Umum, 1989. "Specifikasi bahan bangunan bagian A (bahan bangunan bukan logam)", Departemen Pekerjaan Umum, Jakarta.

Harjoko, M, 1994. Studi Karakteristik Sifat Fisik dan Mekanik Rotan Pada Contoh Uji Kecil Bebas Cat, Fakultas teknologi Pertanian, Institut Pertanian Bogor, Bogor.

Hendrayana, N, 2003. Studi Eksperimental Pengaruh Rotan sebagai Tulangan Terhadap Kuat Lentur Beton $f_{c^{\prime}}=20 \mathrm{MPa}$ dengan Benda Uji Berbentuk Balok.

Hendrayana, T, 2010. Balok Beton Bertulangan Rotan, Berukuran $15 \mathrm{~cm} \times 15 \mathrm{~cm} \times 150 \mathrm{~cm}$, Jurusan Teknik Sipil, Fakultas Teknik, Universitas Katolik

Parahyangan, Bandung Yogyakartar Indonesia, Yogyakarta.

Mulyono, T, 2004. Teknologi Beton, Jurusan Teknik Sipil, Fakultas Teknik, Universitas Negeri Jakarta, Yogyakarta.

Supartono, F, 2008. Beton Mutu Tinggi, Jurusan Teknik Sipil, Fakultas Teknik, Universitas Indonesia, Jakarta.

Tjokrodimuljo, K, 1996. Teknologi Beton, Jurusan Teknik Sipil, Teknik Sipil, Fakultas Teknik, Universitas Islam Indonesia, Yogyakarta.

Fakultas Teknik Universitas Gadjah Mada, 